\title{
Surface Modification of Grey Cast Iron by Pulsed-plasma Deposition and Subsequent Laser Beam Melting
}

\author{
Yu.G. Chabak ${ }^{1}$, V.G. Efremenkoํㅡ, V.I. Fedun ${ }^{1}$, I. Petryshynets ${ }^{2}$, T.V. Pastukhova ${ }^{1}$, \\ B.V. Efremenko ${ }^{1}$, F. Kromka ${ }^{2}$, E.V. Tsvetkova ${ }^{1}$ \\ ${ }^{1}$ Pryazovskyi State Technical University, 7, Universitetskaia St., 87555 Mariupol, Ukraine \\ 2 Institute of Materials Research, Slovak Academy of Sciences, 04001 Kosice, Slovakia
}

(Received 01 December 2020; revised manuscript received 15 April 2021; published online 20 April 2021)

\begin{abstract}
The object of this work is to study the microstructure and wear behavior of grey cast iron superficially modified by pulsed-plasma deposition of the coating and subsequent laser beam melting. The coating 50 vol. \% WC +50 vol. \% Al-bronze of 85-135 $\mu \mathrm{m}$ width was deposited employing an electrothermal axial plasma accelerator with ten pulses under the discharge voltage of $4 \mathrm{kV}$. The coated surface was subsequently melted by infrared fiber laser TruFiber 400 (TRUMPF) with a beam wavelength of $1064 \mathrm{~nm}$ (beam spot was $0.5 \mathrm{~mm}$, scanning velocity was $0.5 \mathrm{~mm} \cdot \mathrm{s}^{-1}$, power was $400 \mathrm{~W}$ ). The investigations included scanning electron microscopy observation (JSM-6510 JEOL), energy-dispersive X-ray spectroscopy (JED2300, JEOL), tribological testing (tribometer Micron-tribo) and microhardness measurement (FM-300, Future-Tech Corp.) under the load of $0.05 \mathrm{~kg}$. After the deposition/laser melting to a depth of up to $600 \mu \mathrm{m}$, the surface was modified from ferrite/lamellar graphite structure to Ledeburite-like eutectic/ $\varepsilon$-copper precipitates structure. The carbide eutectic consisted of fine pearlitic dendrites embedded into a cementite matrix. The structural gradient from fully remelted zone to transitional (carbide/graphite) zone and further to heat-affected zones (with pearlite and ferrite/pearlite matrix structure) was revealed in the cross-section to reach $1250 \mu \mathrm{m}$ in total width. The microhardness of the remelted zone was measured as 900-1000 $\mathrm{HV}_{50}$ to be 5 times higher than that of unmodified structure. The double surface treatment increased the scratch wear resistance of a modified grey cast iron by 15 times as compared to the ferrite/graphite substrate. The effect of copper and tungsten on laser-induced structure formation in grey cast iron is discussed.
\end{abstract}

Keywords: Pulsed-plasma deposition, Composite coating, Laser melting, Microstructure.

DOI: $10.21272 /$ jnep.13(2).02030

PACS numbers: 52.77. - j, 62.20.Qp, 61.66.Dk, 64.70.Kb

\section{INTRODUCTION}

The protective coatings are widely used to enhance the durability of machine parts and tools subjected to erosion wear, corrosion, high-temperature oxidation, etc. $[1,2]$. The coatings are being deposited applying numerous surfacing techniques based on different physical-chemical phenomena including chemical-heat treatment, arc-welding, PVD, HVOF, LMD, etc. [3, 4]. One of the most promising approaches is a combination of different surfacing processes to provide a synergistic effect favorable for surface performance. Vasylyev et al. [5] showed that the low-temperature deposition of $\mathrm{ZrN}$ coating on Al-alloy gives the best result after preliminary $\mathrm{Ar}^{+}$ion bombardment to remove the oxide layer that allows to improve adhesion at the coating/substrate interface. Romankov et al. [6] applied pulsed plasma treatment to enhance the properties of mechanically formed Ti-Al coating. Plasma pulses were also used by Kovaleva et al. [7] to improve the wear resistance of thermally sprayed nanocomposite $\mathrm{Cr}_{3} \mathrm{C}_{2}$ $25 \mathrm{NiCr}$ coatings.

Grey cast iron (GCI) is often used as a research material to study the surfacing processes employing highly concentrated energy sources. Nd:YAG laser beam treatment [8-11] and steady-plasma flux treatment $[12,13]$ are frequently reported to significantly modify the cast iron through its surface melting, involving the transitional from matrix/graphite to matrix/carbide structure. Local laser surface melting allows to employ the biomimetic principle creating the specific modified pattern to increase GCI's dry-sliding wear resistance [14]. The laser (plasma) solid-state processing usually does not provide a notable chemical modification of GCI. The chemical modification of GCI can be obtained by laser surface alloying (LSA) through deep surface melting [15, 16]. Usually LSA uses the gravitational feeding of elements powder into the laser-melted metal pool. The alloying material can also be pre-deposited by electroplating [17] or by overlaying the PVA-based powder-containing paste [18]. However, these techniques are time-consuming or they require specific equipment which limits their applicability for the LSA process. Pre-deposition of the alloying elements can also be fulfilled by the pulsed-plasma deposition (PPD). PPD provides quick formation of the coating due to plasmadriven transfer of the electrode material to the target surface $[19,20]$. The electrodes of plasma accelerator are intensively eroded under the repetitive high-current arc discharges initiated inside the accelerator chamber. The eroded materials (atoms, ions, microdroplets) are ejected out of the accelerator to be directed to the target surface. Thus, the chemical composition of the PPD coating is greatly dependent on the electrode material that allows controlling the coating features through the electrode material selection. The combination of pulsedplasma pre-deposition and laser beam melting has not been well studied yet. Therefore, this issue was in the focus of the present work dedicated to the surface chemical/structural modification of GCI. 


\section{MATERIALS AND METHODS}

The target objects were the specimens with a size of $6 \times 12 \times 25 \mathrm{~mm}$ made of GCI of the following chemical composition (wt. \%): $2.95 \mathrm{C}, 1.45 \mathrm{Si}, 0.95 \mathrm{Mn}, 0.11 \mathrm{P}$, $0.08 \mathrm{~S}$. The initial microstructure of GCI was ferrite grains and graphite flakes. The surface of the specimens was ground to $R_{z}=0.2-0.4 \mu \mathrm{m}$.

Pre-deposition was fulfilled by PPD employing an electro-thermal axial plasma accelerator (EAPA) described in detail in $[19,20]$. The changeable electrode (cathode) coaxially positioned inside the EAPA was a rod of $5 \mathrm{~mm}$ diameter and $60 \mathrm{~mm}$ length fabricated by high-temperature sintering of a powder mixture of 50 vol. \% WC and 50 vol. \% of aluminium bronze ( 5 wt. $\% \mathrm{Al}$ ). The powder particle size was less than $30 \mu \mathrm{m}$. PPD was performed under the following working parameters: the energy accumulated in the capacitor was $12 \mathrm{~kJ}$, the discharge voltage was $4.0 \mathrm{kV}$, the maximal arc discharge current was $18-19 \mathrm{kA}$, the number of discharge pulses was 10 , the distance between the EAPA and the target was $50 \mathrm{~mm}$, the environment was air atmosphere.

After the coating deposition, the surface was subjected to surface laser processing. For this purpose, a fiber laser TruFiber 400 (TRUMPF) with a wavelength of $1064 \mathrm{~nm}$ and a focus distance of $20.5 \mathrm{~mm}$ was used. The coated surface of the specimen was laser beam-scanned in air in a continuous mode. The laser beam spot of $0.5 \mathrm{~mm}$ diameter was scanned with a velocity of $5 \mathrm{~mm} \cdot \mathrm{s}^{-1}$ under the power of $400 \mathrm{~W}$. The scanning lines were located close to each other without gaps. During the scanning, the specimens were positioned on the copper plate to remove heat from the laser-affected zone. The laser-treated specimen was cooled in calm air.

The cross-sectional microstructure was studied after etching with a 4 vol. \% nital reagent using an optical microscope Axiovert 40M (Carl Zeiss) and a scanning electron microscope JSM-6510 LV (JEOL). The elemental phase composition was examined using an energy-dispersive spectroscopy (EDS-detector JED2300, JEOL). Microhardness was measured using Affri tester at a load of $0.05 \mathrm{~kg}$. The wear test was performed using the Micron-tribo tribometer under the reciprocating movement back and forth (200 strokes) of the diamond $120^{\circ}$-cone with a normal load of $0.45 \mathrm{~kg}$. The profile of the wear track was studied using the interference Micron-beta profilometer.

\section{RESULTS}

\subsection{Microstructure Characterization}

Fig. 1 illustrates the microstructure of the pulsedplasma coating deposited on the GCI surface using the bronze/WC composite cathode. As seen, the coating consisted of an intermediate layer and an outer layer with a total width varied in the range of 85-135 $\mu \mathrm{m}$. The coating contained the roundish or angular carbide precipitates of $0.1-9.3 \mu \mathrm{m}$ in size distributed in a metallic matrix. The most of precipitates (with the carbide volume fraction of about 30-50 vol. \%) were concentrated in the outer layer, while the intermediate layer contained only 5-10 vol. \% carbide. As follows from the EDS spectrum presented in Fig. 2a, the precipitates were WC carbide with the chemical composition close to WC stoichiometry. Notably, copper (2.65 wt. \%) and aluminium $(0.26 \mathrm{wt} . \%)$ were found in WC. The unusually high contents of $\mathrm{Cu}$ and $\mathrm{Al}$ in tungsten carbide were referred to carbide interaction with a plasma flux during the PPD process. The matrix of the coating was $\mathrm{Cu}$-based ( 79 wt. \%) with additions of $\mathrm{Fe}$, $\mathrm{W}, \mathrm{Al}$, Si (Fig. 2b) to be originated from the bronze component of the EAPA cathode. The $\mathrm{Al}$ content in the coating matrix sharply decreased relative to the initial bronze composition. Specifically, the aluminium content in the matrix (intermediate layer) was recorded as $0.52 \mathrm{wt}$ \% to be 10 times lower as compared to bronze that can be explained by intensive aluminium oxidation in a plasma flux.

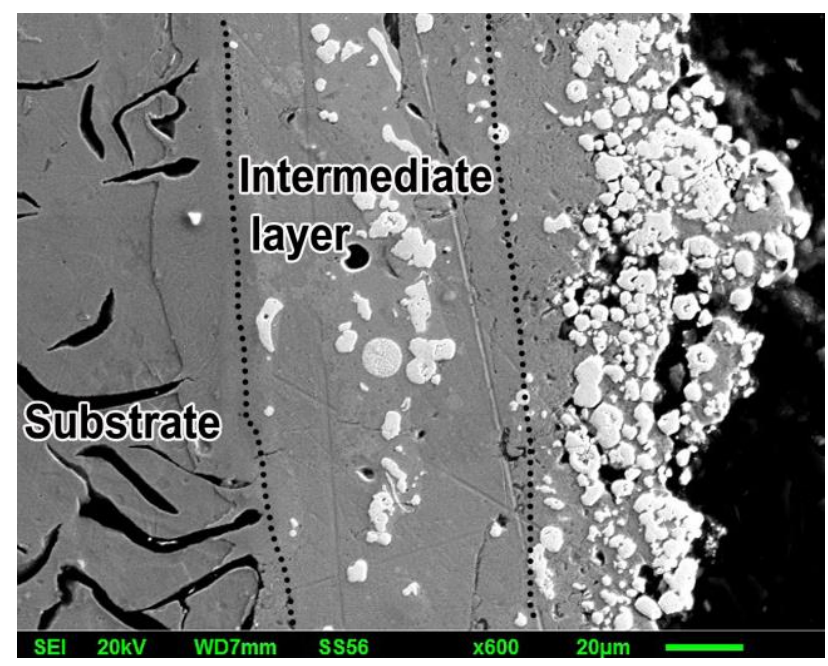

Fig. 1 - SEM image of the coating

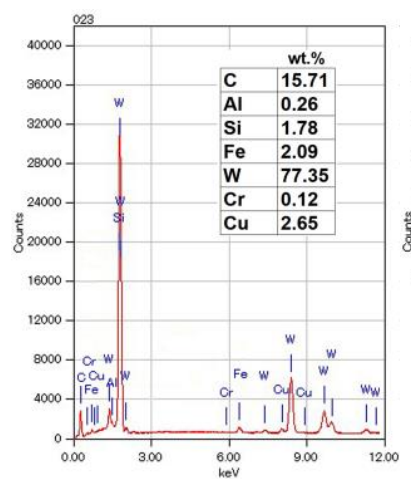

a

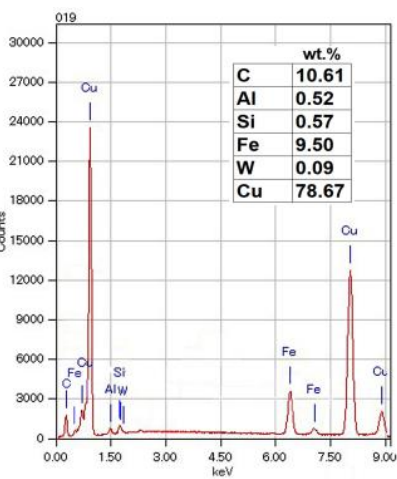

b
Fig. 2 - EDS spectra of coatings: (a) WC carbide, (b) matrix in the intermediate layer

The PPD treated surface was processed by laser beam melting (LM) as described above. As a result, the modified layer appeared on the specimen surface depicted by the arrow in Fig. 3. The width of this layer within the specimen increased from $450 \mu \mathrm{m}$ on the left side (the place of LM start) to $830 \mu \mathrm{m}$ on the right side (the place of LM finish). Alteration of the layer width was caused by heat accumulation inside the specimen under laser beam scanning. As seen in Fig. 4, as the 
laser beam scanned over the specimen surface, its temperature increased significantly as revealed by the specimen glow to the end of LM processing. Accordingly, heat removal from the surface inside the specimen decreased causing deeper melting.

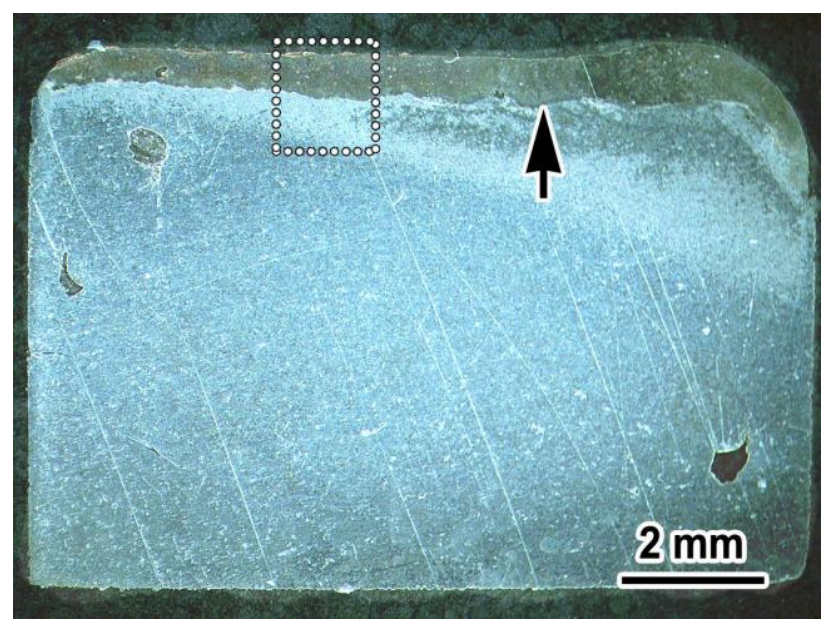

Fig. 3 - The cross-section of the laser-treated specimen



a

$\mathrm{b}$

Fig. 4 - Heating of the specimen under laser beam scanning (from the beginning (a) to the finish (c))

PPD/LM processing resulted in a drastic change in GCI's structural status. The cross-section of the treated specimen is presented in Fig. 5a and corresponds to the area depicted by the dotted line in Fig. 3. Fig. 5a gives a total view of the modified layer consisting of four zones namely: 1 - remelted zone, 2 - transitional zone, 3 - heat affected zone $\mathrm{HAZ}_{1}$, and $4-\mathrm{HAZ}_{2}$. The remelted zone had a Ledeburite-like eutectic microstructure, its width varied within Fig. 5a from $445 \mu \mathrm{m}$ to $595 \mu \mathrm{m}$. The classical Ledeburite is composed of the austenite fibers embedded into a cementite matrix as a result of synchronous growth of two phases [21]. On the contrary, in the studied case the fine dendrites of pearlite (former austenite) were branched in a cementite matrix (Fig. 5b) meaning that austenite crystallized first before cementite crystallization. The dendrites of up to $200 \mu \mathrm{m}$ length were randomly oriented regarding the specimen surface. The width of the dendrite branch was 0.5$2.0 \mu \mathrm{m}$, the secondary arm length was up to $12 \mu \mathrm{m}$, the secondary arm spacing was 1.1-2.5 $\mu \mathrm{m}$. Apart from Ledeburite-like eutectic, Cu-rich globules of 3-22 $\mu \mathrm{m}$ in diameter with a volume fraction of 7 vol. \% were spread

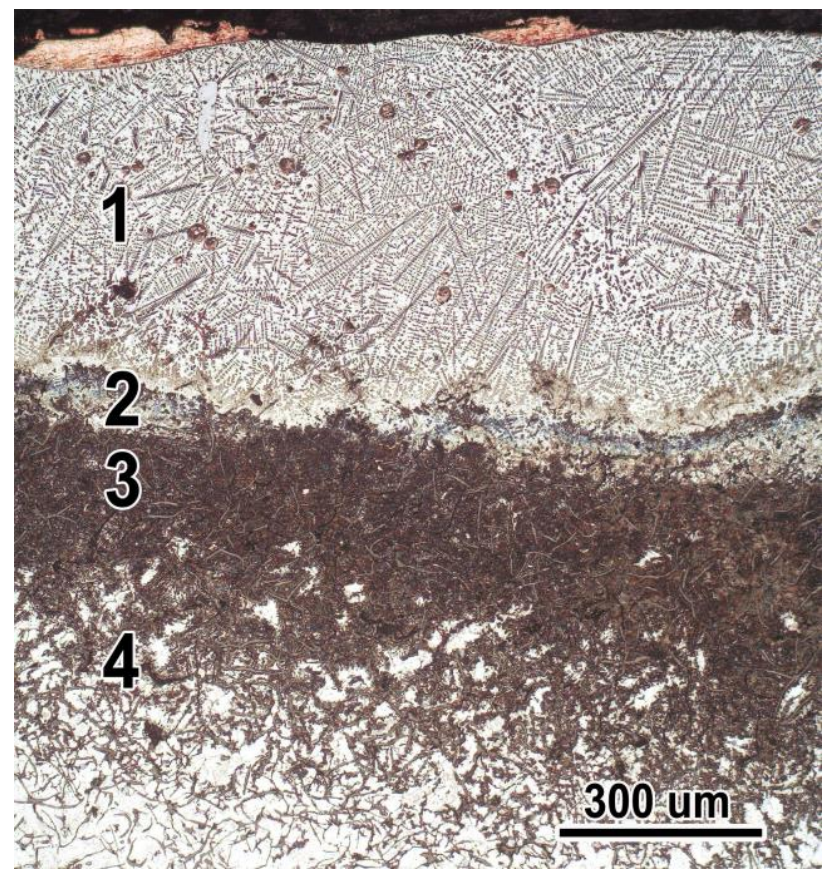

a

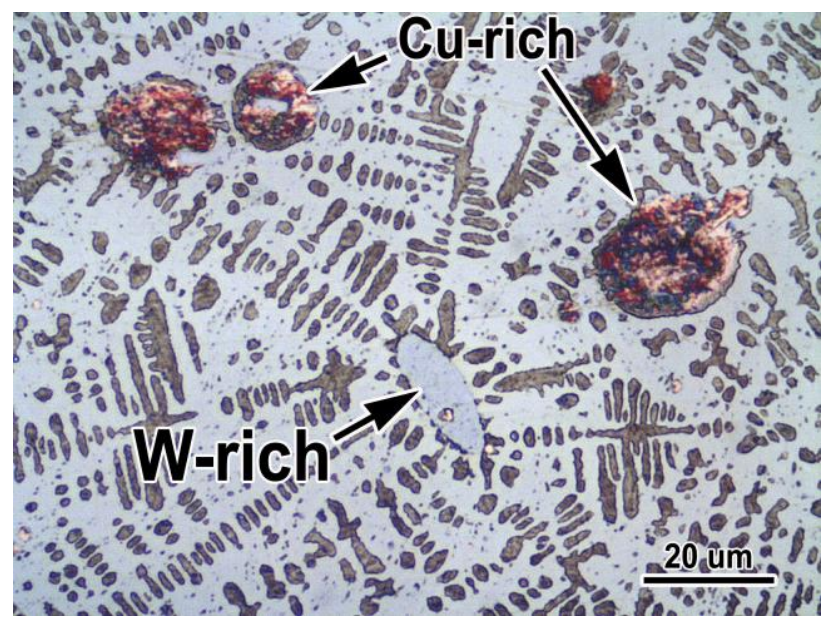

$\mathrm{b}$



c 


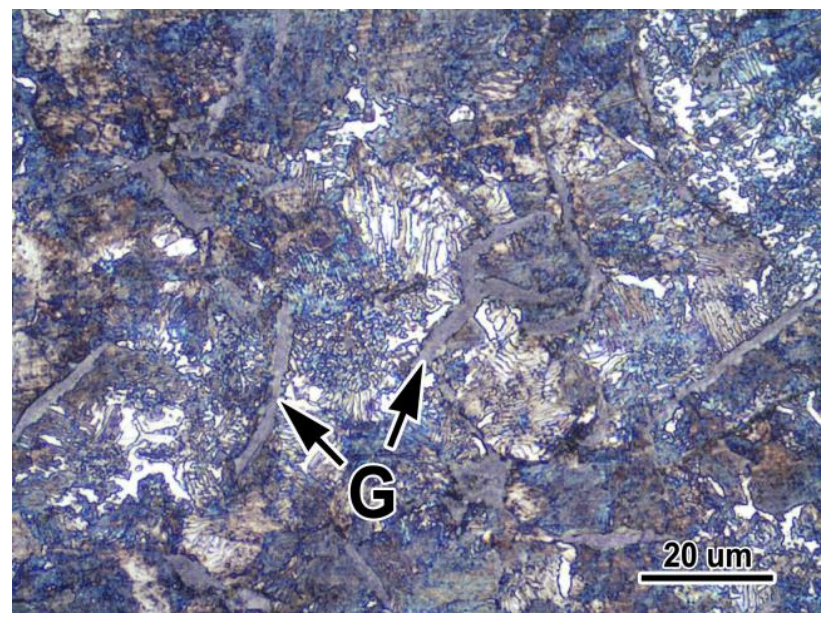

d



e

Fig. 5 - GCI microstructure after PPD/LM treatment: (a) total view, (b) remelted zone, (c) transitional zone, (d) HAZ, (e) $\mathrm{HAZ}_{2}(\mathrm{C}$ - carbide, $\mathrm{G}$ - graphite $)$

over the remelted zone to be embedded into a cementite matrix. Also, Cu-rich films of up to $50 \mu \mathrm{m}$ width were revealed on the specimen surface.

Occasional precipitates of high hardness (presumably W-rich) were observed in the structure of the remelted zone to be as nuclei for the austenite dendrites growth (Fig. 5b). WC carbides in their initial state were not seen in the structure meaning their complete dissolution under LM. No sight of graphite was found in the remelted zone.

Towards the interior of the specimen, the remelted zone evolved into the transitional zone where carbide and graphite flakes were seen both (Fig. 5c). In this zone, Ledeburite-like eutectic transforms to the "divorced" eutectic [22] with thin carbide lamellas. The width of the transitional zone was about 100-150 $\mu \mathrm{m}$. Thus, the remelted and transitional zones with a total width of up to $\sim 750 \mu \mathrm{m}$ were associated with the depth of specimen melting under the laser beam action. Outside these zones, the structure contained only graphite flakes while carbides were absent.

The deeper layers were the heat-affected zones, where the solid-state phase transformation occurred under the LM processing. The $\mathrm{HAZ}_{1}$ zone of 200$230 \mu \mathrm{m}$ width had graphite lamellas and a fully pearlitic matrix (Fig. 5d). The $\mathrm{HAZ}_{2}$ zone of 300-400 $\mu \mathrm{m}$ width had a ferrite-pearlite matrix (Fig. 5e). Within $\mathrm{HAZ}_{2}$, as moving deeper, the amount of pearlite decreased, and the amount of ferrite increased. The total depth of laser beam-induced modification (liquidstate and solid-state) was 1050-1250 $\mu \mathrm{m}$.

\subsection{Microhardness and tribological behavior}

Fig. 6 presents the microhardness profile across the modified layer. The remelted zone had a high microhardness of 900-1000 $\mathrm{HV}_{50}$ with its further gradual decrease towards the specimen center. In the transitional zone, the microhardness varied with a large scatter (in the range of 500-850 $\mathrm{HV}_{50}$ ) to be caused by different carbide/graphite ratio within the zone. In $\mathrm{HAZ}_{1}$, the microhardness was $320-480 \mathrm{HV}_{50}$. In $\mathrm{HAZ}_{2}$, the microhardness gradually reduced from $\mathrm{HAZ}_{1}$ level to $200 \mathrm{HV}_{50}$ which is the substrate (ferrite + graphite) level. Thus, PPD/LM treatment resulted in a 5 -fold increase in the GCI surface microhardness.

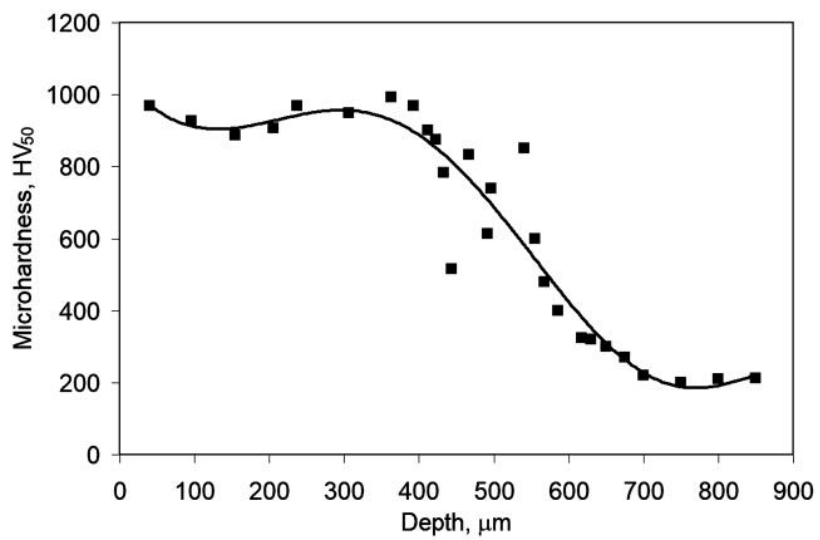

Fig. 6 - The microhardness profile across the modified layer

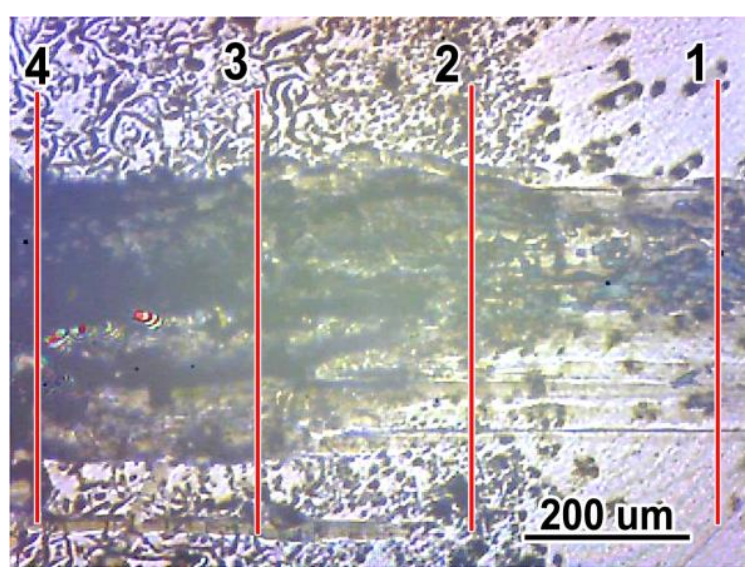

Fig. 7 - The view of the wear track across the modified layer: 1 -remelted zone, 2 - transitional zone, 3 - $\mathrm{HAZ}_{1}, 4$ - substrate

The tribological behavior of PPD/LM modified GCI was studied under the scratching by a diamond pyramid. Fig. 7 presents the view of the wear track which goes across the different zones. As seen, as moving from the remelted zone (right side) to the unmodified structure (left side), the wear groove becomes wider and rougher 
reflecting the intensification of the wear process. The groove profile was measured along transverse lines 1-4 (shown in Fig. 8) which correspond to the different modified zones.

The wear track in the remelted zone is characterized by a smooth relief with a maximum profile height of $0.33 \mu \mathrm{m}$ (see the insert in Fig. 8). The profile height of the transitional zone increased to $0.82 \mu \mathrm{m}$ which is consistent with the microhardness profile. The unmelted heat-affected zone $\mathrm{HAZ}_{1}$ had a significantly increased profile height $(1.72 \mu \mathrm{m})$, which was 5 times greater than that of the remelted zone. The wear resistance of the unmodified substrate was even worse with a profile height of 15 times to the remelted zone $(4.98 \mu \mathrm{m})$. The wear test allowed to conclude that the laser-melted zones performed much better resistance to the scratching as compared to $\mathrm{HAZ}_{1}$ and the unmodified substrate.

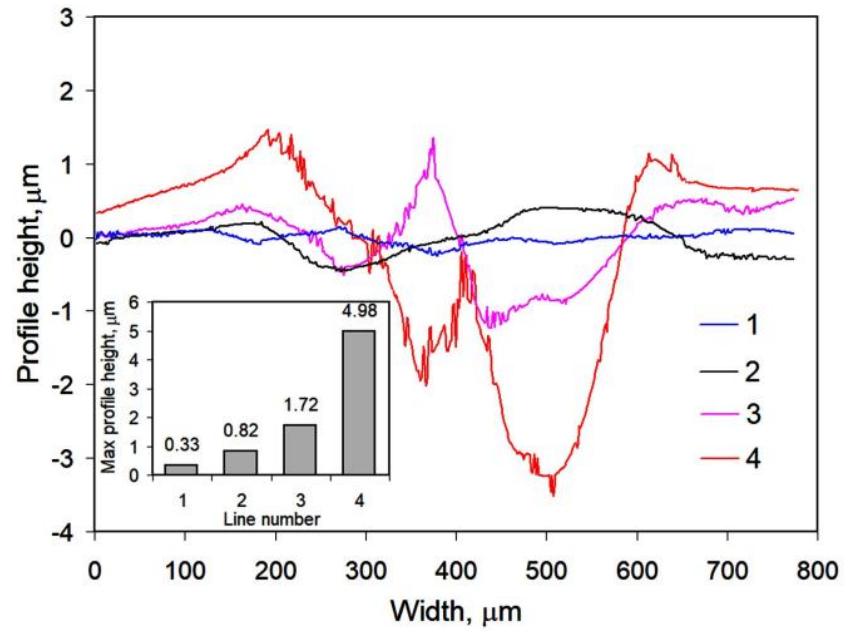

Fig. 8 - The cross-sectional profiles of the wear track along the lines shown in Fig. 7

\section{DISCUSSION}

As shown in this work, the LM resulted in a significant alteration of the structural status of GCI. During the melting, the graphite lamellas completely dissolved saturating the melt with carbon. Due to heat removal from the surface deep into the specimen, the carbon-rich melt crystallized with a high cooling rate according to the non-equilibrium path with cementite formation instead of graphite. This phase transformation is favorable for abrasive applications [23]. Ledeburite-like eutectic appeared in remelted zones causing a 5 -fold increase in microhardness and a 15 -fold increase in wear resistance. Since the LM was preceded by $\mathrm{PPD}$ of a bronze/WC layer, copper and tungsten certainly affected the crystallization of the molten layer due to thermodynamic and kinetic factors.

The pulsed-plasma $\mathrm{Cu} / \mathrm{W}$-rich coating with an average width of $110 \mu \mathrm{m}$ had a microstructure consisting approximately of $25 \mathrm{vol} \% \mathrm{WC}$ and $75 \%$ bronze. Taken the copper and tungsten concentration as shown in Fig. 2, the average coating composition can be roughly estimated as 19.3 wt. \% W and 59.2 wt. \% Cu. Under the laser beam, the coating was melted, thus its structural components were fully dissolved in the melt (including WC carbides as evidenced from Fig. 3b). Accordingly, the surface was $\mathrm{Cu} / \mathrm{W}$-alloyed. The total melting depth (of $550 \mu \mathrm{m}$ on average) was 5 times higher than the coating width, thus dilution of copper and tungsten within the molten pool should take place. Due to the dilution, the mean concentrations of copper and tungsten in the remelted zone can be approximately evaluated as 11.7 wt. \% and 3.9 wt. \%, respectively.

The effect of copper on the GCI structure is described in [24-27]. The globular Cu-rich inclusions shown in Fig. 3c were presumably $\varepsilon$-copper precipitated in a high-temperature domain as a result of the separation of a melt into Fe-rich and $\mathrm{Cu}$-rich fractions [24]. As follows from [25], with an increase in the copper content of more than $6 \mathrm{wt} . \%$, the thermal conductivity of the liquid and solid phases increases leading to (a) a decrease in austenite crystallization temperature range (promoting the formation of fine austenite dendrites in the remelted zone), (b) chilling the cast iron favoring Ledeburite formation [26], and (c) an increase in the pearlite dispersion, i.e. the matrix microhardness. Moreover, precipitation of nanosized $\varepsilon$-copper particles inside the ferrite lamellas occurs to be an additional strengthening factor for $\mathrm{Cu}$-rich cast irons. As shown in [27], $\varepsilon$-copper particles interact with dislocations by the Orowan loop mechanism, while the cross-slip (cutting) mechanism is not manifested. Additionally, $\varepsilon$-copper precipitates contribute to dry-sliding wear resistance behaving as a solid lubricant [28].

Tungsten is a carbide-forming element that facilitates the chilling of GCI. Tungsten decreases the carbon content in the eutectic point, thus increasing the volume fraction of the carbide phase [29]. When the tungsten content in cast iron is less than $10 \%$, it does not form W-rich carbides $\left(\mathrm{M}_{6} \mathrm{C}, \mathrm{M}_{2} \mathrm{C}, \mathrm{MC}\right)$ [30]. Instead, it dissolves in cementite, leading to an increase in cementite microhardness. In summing, tungsten has also contributed to the modification of the properties of the studied GCI.

\section{CONCLUSIONS}

The phase-chemical modification of GCI was fulfilled using the PPD of $50 \mathrm{vol} . \% \mathrm{WC} / 50$ vol. \%Al-bronze coating (85-135 $\mu \mathrm{m}$ width) and subsequent laser beam melting. As a result of $\mathrm{Cu} / \mathrm{W}$ surface alloying and fast crystallization, the initial ferrite/graphite structure was modified to a Ledeburite-like eutectic $+\varepsilon$-copper precipitates structure to the depth of up to $640 \mu \mathrm{m}$. Eutectic was composed of fine austenite dendrites branched in a cementite matrix. The total depth of laser beam-induced modification (liquid-state and solid-state) was up to $1250 \mu \mathrm{m}$. The double $\mathrm{PPD} / \mathrm{LM}$ treatment resulted in a 5 -fold increase in microhardness (to 900$1000 \mathrm{HV}_{50}$ ) and a 15-fold increase in wear (scratch) resistance as compared to the unmodified substrate.

\section{ACKNOWLEDGEMENTS}

This work was sponsored by the National Research Foundation of Ukraine within the project 2020.02/0064 «Phase-structural and elemental surface modification of 3D-printed alloys for biomedical application during the complex processing by highly concentrated energy 
sources to increase the service life of artificial implants». Chabak Yu.G. also thanks to the Ministry of
Education and Science of Ukraine for the support within the project No 0119U100080.

\section{REFERENCES}

1. I.M. Spiridonova, E.V. Sukhovaya, S.B. Pilyaeva, O.G. Bezrukavaya, Metall. Gornorudn. Prom-st 3, 58 (2002).

2. O.V. Sobol, A.A. Andreev, A.A. Meylekhov, A.A. Postelnyk, V.A. Stolbovoy, I.M. Ryshchenko, Yu.Ye. Sagaidashnikov, Zh.V. Kraievska, J. Nano-Electron. Phys. 11 No 1, 01003 (2019).

3. Z.A. Duriagina, I.A. Lemishka, A.M. Trostianchyn, V.V. Kulyk, S.G. Shvachko, T.L. Tepla, E.I. Pleshakov, T.M. Kovbasyuk, Powder Metall. Met. Ceram. 57, 697 (2019).

4. N.S. Mashovets, I.M. Pastukh, S.M. Voloshko, Appl. Surf. Sci. 392, 356 (2017).

5. M.A. Vasylyev, B.N. Mordyuk, S.I. Sidorenko, S.M. Voloshko, A.P. Burmak, I.O. Kruhlov, V.I. Zakiev, Surf. Coat. Technol. 361, 413 (2019).

6. S. Romankov, A. Mamaeva, S.D. Kaloshkin, S.V. Komarov, Mater. Let. 61, 5288 (2007)

7. M.G. Kovaleva, V.V. Sirota, V.M. Beresnev, Y.N. Tyurin, O.N. Vagina, I.A. Pavlenko, J. Nano-Electron. Phys. 10, 06035 (2018).

8. S.S. Aziz, A.S. Alwan, K.A. Abed, Biochem. Cell. Arch. 1, 1587 (2019).

9. A.R. Zulhishamuddin, S.N. Aqida, E.A. Rahim, AIP Conf. Proceed. 1769, 030004 (2016).

10. N. Pagano, V. Angelini, L. Ceschini, G. Campana, Procedia CIRP CMS 2015 41, 987 (2016).

11. K.Y. Benyounis, O.M. Fakron, J.H. Abboud, A.G. Olabi, M.S.J. Hashmi, J. Mater. Process. Technol. 170 No 1-2, 127 (2005).

12. X. Cheng, S. Hu, W. Song, X. Xiong, Vacuum 101, 177 (2014).

13. B.-Y. Jeong, J.-H. Chang, M.-H. Kim, Surf. Coat. Technol. 205 No 3, 896 (2010).

14. Q. Sui, H. Zhou, H. Zhang, L. Feng, L. Yang, P. Zhang, J. Mater. Res. 32 No 2, 343 (2017).
15. A. Kotarska, Welding Technol. Rev. 91 No 5, 19 (2019).

16. G.F. Sun, C. Sheng, L.J. Liang, J.H. Zhou, X.Q. Tao, Adv. Mater. Res. 79-82, 1459 (2009).

17. A. Hussain, I. Ahmad, A.H. Hamdani, A. Nussair, S. Shahdin, Appl. Surf. Sci. 253 No 11, 4947 (2007).

18. N. Jeyaprakash, Che-Hua Yang, Muthukannan Duraiselvam, G. Prabu, Results Phys. 12, 1610 (2019).

19. Yu.G. Chabak, V.I. Fedun, T.V. Pastukhova, V.I. Zurnadzhy, S.P. Berezhnyy, V.G. Efremenko, Probl. At. Sci. Technol. Ser.: Plasma Phys. 110 No 4, 97 (2017).

20. Yu.G. Chabak, V.I. Fedun, V.G. Efremenko, T.V. Pastukhova, B.V. Efremenko, Probl. At. Sci. Technol., Ser.:Plasma Phys. 123 No 5, 167 (2019).

21. M. Trepczyńska-Łent, Arc. Foundry Eng. 7(3), 171 (2007).

22. M. Zhu, L. Zhang, H. Zhaoa, D.M. Stefanescu, Acta Mater. 84, 413 (2015).

23. Yu.G. Chabak, V.G. Efremenko, Metallofiz. Noveishie Tekhnol., 34, 1205 (2012).

24. O.K. von Goldbeck, Iron-Copper. In: Iron-Binary Phase Diagrams (Berlin: Springer: 1982).

25. N.V. Stepanova, A.A. Razumakov, E.A. Lozhkina, Appl. Mech. Mater. 682, 178 (2014).

26. G.I. Silman, V.V. Kamynin, V.V. Goncharov, Metal Sci. Heat Treatment 49, 387 (2007).

27. I.A. Bataev, N.V. Stepanova, A.A. Bataev, A.A. Nikulina, A.A. Razumakov, Phys. Met. Metallogr. 117 No 9, 901 (2016).

28. J. Agunsoye, S. Bello, S. Hassan, R. Adeyemo, J. Odii, J. Miner. Mater. Charact. Eng. 2, 470 (2014).

29. Niu Libin, Xu Yun-hua, Peng Jian-hong, Wu, Hong, China Foundry 6, 333 (2009).

30. B. Uhrenius, Calphad-computer Coupling of Phase Diagrams and Thermochemistry 4, 173 (1980).

\title{
Модифікація поверхні сірого чавуну імпульсно-плазмовим осадженням та подальшим лазерним оплавленням
}

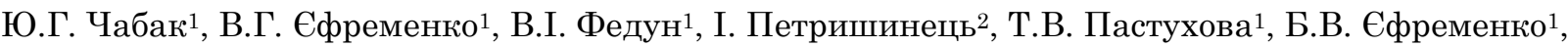 \\ Ф. Кромка ${ }^{2}$ О.В. Цветкова ${ }^{1}$
}

1 Приазовський державний технічний університет, вул. Університетська, 7, 87555 Маріуполь, Украӥна

2 Institute of Materials Research, Slovak Academy of Sciences, 04001 Kosice, Slovakia

\begin{abstract}
Метою даної роботи є дослідження мікроструктури та зносостійкості сірого чавуну, поверхнево модифікованого імпульсно-плазмовим нанесенням покриття 3 подальшим плавленням лазерним променем. Композиційне покриття 50 об. \% WC + 50 об. \% Al-бронзи товщиною 85-135 мкм було нанесено із застосуванням електротермічного аксіального плазмового прискорювача плазми (10 плазмових імпульсів із напругою розряду 4 кВ). Після нанесення покриття поверхню оплавили скануванням інфрачервоним лазерним променем з довжиною хвилі 1064 нм. При цьому застосували волоконний лазер TruFiber 400 (TRUMPF), діаметр плями променю становив 0,5 мм, швидкість сканування 0,5 мм.с-1, потужність 400 Вт. В роботі застосували мікроструктурний аналіз (скануючий електронний мікроскоп JSM-6510 JEOL), енергодисперсійну рентгенівську спектроскопію (EDS детектор JED-2300 JEOL), трибологічні випробування (трибометр Мікрон-трибо) та вимірювання мікротвердості при навантаженні 50 г (мікротвердомір FM-300, Future-Tech Corp.). В результаті лазерного оплавлення на глибину до 600 мкм, яке супроводжувалось поверхневим легуванням чавуну міддю та вольфрамом, мікроструктура чавуну змінилась з ферит + пластинчастий графріт на ледебурітоподібну карбідну евтектику 3 глобулярним включеннями $\varepsilon$-міді. Карбідна евтектика складалася 3 дисперсних дендритів із перлітною структурою, розгалужених в матриці цементитного карбіду. У поперечному перерізі мікроструктура змінювалась градієнтно від повністю оплавленої зони до перехідної карбідо-графітної зони і далі до зон термічного впливу з перлітною або фреритоперлітною структурою загальною шириною до 1250 мкм. Мікротвердість оплавленої зони становила 900-1000 $\mathrm{HV}_{50}$, що в 5 разів вище за вихідну мікроструктуру чавуну. Подвійна поверхнева обробка
\end{abstract}


збільшила зносостійкість сірого чавуну в 15 разів порівняно зі структурою ферит + графіт. В статті обговорюеться вплив міді та вольфраму на формування структури сірого чавуну при лазерному оплавленні.

Ключові слова: Імпульсно-плазмове нанесення, Композиційне покриття, Лазерне оплавлення, Мікроструктура. 